\title{
Of Human Responsibility: Considering the Human/ Environment Relationship and Ecosystems in the Anthropocene
}

\author{
Karen Morrow
}

\begin{abstract}
Whilst there is widespread agreement in scientific and academic circles, and increasingly in the more radical reaches of a whole range of social and political spheres, that the existential challenges posed by the Anthropocene require nothing less than a wholesale re-fashioning of the human-environment paradigm; how this might be achieved remains, at best, highly debatable. The exploitative archetype of mastery over nature is deeply ingrained within our species' psyche and praxis, and it has, on balance, served us well for most of our evolutionary development. Where human behaviour has imposed costs on the natural world, the latter has, broadly speaking, long proved remarkably resilient in absorbing much of the impact of our excesses. Nonetheless, all indications are that this will not be the case in perpetuity and that, as we transgress an increasing number of crucial planetary boundaries, our habitual ways of thinking and behaviours represent an existential threat to at least our own species, if not the biosphere as a whole. Our increasing (if still woefully incomplete) knowledge how planetary systems function and the significance of the impacts of human activities upon them could, if acted upon swiftly, and with a thorough-going commitment that recognises the true position of humans within the biosphere and the consequent imperative to curb our own over-indulgence, represent our best chance to continue to flourish as a species in a viable global context. Achieving such a fundamental alteration in our ontological perspective would arguably represent a seismic shift in human affairs on a par with the Enlightenment. In the past we have enjoyed the luxury of experiencing such change as gradual evolution, but current conditions require our next perspectival shift to be achieved with an unprecedented degree of urgency. This chapter considers one area in which we might trial our ability to adopt reasoned behavioural change that short-circuits norms that have ultimately become counterproductive: our relationship to ecosystems. This is the area where the human-nature nexus and the implications of its current malignant pathology are arguably at their most immediate. A plethora of potential routes have been identified in order to recraft the terms of this aspect of our interconnection with nature in a more sustainable fashion. This chapter will look specifically at the voguish but vexed concept of ecosystems services, arguing that, as currently envisaged, rather than representing innovation, it pursues the paradigm of mastery to its logical and damning conclusion. The chapter will briefly consider the pros and cons of applying selected rights-based approaches (representative of an important strand in current thinking in this area) in the context of ecosystems services as correctives to this course. The rights approaches considered include: (likely prevailing) individual property rights; collective human rights; and 'rights for nature' archetypes. The chapter will conclude by considering the idea that, while rights discourse has something to offer in this context, where human attitudes and behaviour are in play, absent the crucial counter-point of an ethic of human responsibility, it cannot offer more than a partial solution to the conundrum of how to fashion a sustainable version of the human-environment bond.
\end{abstract}

(H) The Paradigm of M astery and its Consequences

The current prevailing paradigm shaping the human/nature relationship, while it has until quite recently, served (or at least appeared) to promote human flourishing, has now reached the point where it must be regarded as inherently unsustainable. In recognising the shift to the Anthropocene, 
we are coming to understand that our cosmology, the dominant ${ }^{1}$ epistemology founded upon it, and resulting global praxis, has set us on a trajectory that is changing the face of the biosphere to the point that it poses multiple, potentially existential, threats to our species, ${ }^{1}$ and is re-shaping the nature of life itself. ${ }^{1}$ Critique of this state of affairs is ubiquitous; here though, discussion will draw on ecofeminist scholarship, and in particular the germinal work of Val Plumwood on what she terms the 'paradigm of mastery'. ${ }^{1}$ Central to Plumwood's analysis for present purposes is the application of the prevailing post-Enlightenment Western philosophical conception of dualism ${ }^{1}$ to delineate, differentiate, and distinguish, between (human) culture and nature. In this context, she points to the centrality of 'denied dependency' ${ }^{1}$ in the human/nature relationship. In sum, the approach separates the realm of the human/master and reason from environment/nature, whereby:

To be defined as 'nature' ... is to be defined as a terra nullius, a resource empty of its own purposes or meanings, and hence available to be annexed for the purposes of those supposedly identified with reason or intellect ... ${ }^{1}$

Law has been profoundly implicated in this annexation of nature to human purposes. As Stone observes, natural objects:

... have traditionally been regarded by the common law, and even by all but the most recent legislation, as objects for man to conquer and master and use ... and even where natural objects are conserved this is done 'for us'. ${ }^{1}$

The paradigm of mastery is characterised by Plumwood as invoking a '... multiple, complex cultural identity of the master formed in the context of class, race species and gender domination ...' ${ }^{1}$ and for present purposes it essentially casts the environment/nature as inherently inferior and a means to privileged humanity's ends, rendering it ripe for what is assumed to be self-evidently justified and thus largely unquestioned exploitation. Interestingly, psychology refers to the 'mastery perception' as a motivation for active attempts to govern one's environment ${ }^{1}$ but - worryingly in the context of ecological crisis - points to the fact that if control goals are not attained, disengagement results (in order to conserve physical and - in humans - emotional resources). ${ }^{1}$ We can now understand the pursuit of the paradigm of mastery as a form of malignant pathology, the adverse consequences of which for the environment, are amply evidenced in resource depletion, pollution, ecosystem and

\footnotetext{
${ }^{1}$ While there are numerous (indigenous/religious) world views that situate humanity as part of nature, rather than as its master, these currently represent counter-hegemonic perspectives, rather than accepted orthodoxy see, for example, John A. Grim, Indigenous traditions and ecology: the interbeing of cosmology and community (Harvard University Press 2001).

${ }^{1}$ See the work of the Stockholm Resilience Centre on planetary boundaries, which focuses on those areas of the biosphere that most directly support human life, and which are subject to varying degrees of threat, notably W. Steffen et al., 'Planetary Boundaries: Guiding human development on a changing planet' (2015) Science Vol. 347 no. 622315 January 2015, DOI: 10.1126/science.1259855.

${ }^{1}$ See Alan Weisman, The World Without Us (Virgin Books 2008) which suggests that, absent humanity, life on Earth would continue, though potentially in radically different fashion.

${ }^{1}$ Val Plumwood, Feminism and the M astery of Nature (Routledge 1993).

$1 \mathrm{lbid}$, Chapter 2.

1 Ibid, 41.

${ }^{1} \mathrm{lbid}, 4$.

${ }^{1}$ Christopher D. Stone, 'Should Trees Have Standing - Towards Legal Rights for Natural Objects' 45 (1972)

Southern California Law Review 450, 463.

1 Plumwood n4, 5.

1 Jutta Heckhausen, 'Evolutionary perspectives on human motivation' 43.6 The American Behavioral Scientist (2000) 1015,1023

1 lbid 1024.
} 
ultimately even biospheric disruption, and all too apparent. ${ }^{1}$ Less discussed, and little investigated but arguably no less important are the consequences of enjoying the ultimately illusory position of mastery for humanity as a species: treating nature as a mere means to human ends has led us to develop a finite and ultimately erroneous sense of god-like superiority and as we enter the Anthropocene, the moral and physical toxicity of this is becoming increasingly evident.

Our now rapidly emerging scientific understanding of the complexities of the functioning of the biosphere and of the existence of systemic planetary boundaries mean that we no longer have any excuse for viewing the paradigm of mastery as anything more than an illusion founded on selfserving delusion. As Plumwood points out, we are well aware that the biosphere is no mere 'background part of our field of action or subjectivity', ${ }^{1}$ and ecology has (re)introduced us to the profound knowledge that that we are intimately enmeshed in nature, rather than separate from, or in any way above it. While these are things that on one level we know, we have yet to truly grasp their import ${ }^{1}$ and express this centrally in the way that we conduct ourselves vis-à-vis the environment. Rather, we have made comparatively minor adjustments to some of our more egregiously damaging activities under the auspices of environmental law, but these have in not altered the fundamental underlying paradigm of mastery. Dis/ replacing the paradigm will be challenging, for as Plumwood convincingly argues, ending the systemic bifurcation of dualism and according value to the other cannot be addressed by mere merger or even reversal of current approaches ${ }^{1}$ - something much more ambitious is required, entailing: '... recognition of a complex, interacting pattern of both continuity and difference'. ${ }^{1}$

When applied to the human/nature relationship, this observation enables us to garner important insights: in terms of continuity, it acknowledges that humans are undoubtedly part of nature, and indeed intimately and entirely enmeshed within it; at the same time, in terms of difference, humans are distinct from the rest of nature in our ability to manipulate natural systems on a variety of scales from local to, now, planetary. In some ways, locally, and in the short term, humanity has been able to sway nature our own ends (though not entirely and with unintended consequences and externalities); it is however now becoming clear with the advent of the Anthropocene, that the cumulative spatial and temporal impacts of human activity pose such substantial threats that we urgently need to rethink our place in the biosphere. This brings us to the central question: what would it require to motivate the shift that this would need to engage in the dynamics and characterisation of the human/nature relationship? Human history has shown that societal (and legal) responses to moral/ethical arguments for altering key aspects of human behaviour are comparatively slow to develop, partial in their draw, and ultimately require legal compulsion for their realisation. ${ }^{1}$ When we do respond to such imperatives, as Delgado puts it:

... we are almost inevitably drawn to doomed, moderate approaches ... when society needs more sweeping, ambitious ones. We resist precisely the medicine that could save us. We turn to strong solutions only when it is either too late, or when our thinking has advanced so far that the solutions seem commonplace and tame. ${ }^{1}$

\footnotetext{
${ }^{1}$ Steffen et al. $\mathrm{n} 2$.

${ }^{1}$ Val Plumwood: 'Ecological Ethics from rights to recognition: multiple spheres of justice for humans, animals and nature.' in Nicholas Low (ed.) Global Ethics and Environment (Routledge 1999) 197.

${ }^{1}$ See, for example, Donald A. Hantula, 'Evolutionary Psychology and Consumption' 20.9 Psychology \& Marketing (2003) 757 and George Marshall, Don't Even Think About It: Why Our Brains Are Wired to Ignore Climate Change (Bloomsbury 2014).

${ }^{1}$ Plumwood, n4, 59-64.

1 Plumwood, n4, 67.

${ }^{1}$ See, for example, discussion of developments in gender equality and abolishing slavery as discussed in Stone n8.
} 
This is clearly applicable to the current context, wherein it may be argued that, in the past, we could allow ourselves the luxury of shifting perspectives through societal evolution, rather than revolution: in the Anthropocene, in a world of relatively rapid human-induced change, tipping points and interconnected/systemic threats this is no longer be the case. Swift change requires a rapid response. So, if we cannot fashion an effective morally-prompted new relationship between environmental ethics, law and societal practice, desirable in principle as this may be, ${ }^{1}$ can practical considerations - and scientific evidence furnished by ecology (itself the subject of rapid and radical development ${ }^{1}$ ) - supply the deficit?

In this context, as Folke et al. observe:

The old way of thinking implicitly assumes a stable and infinitely resilient environment, a global steady state. The new perspective recognizes that resilience can be and has been eroded and that the self-repairing capacity of ecosystems should no longer be taken for granted. ${ }^{1}$

One potential response to this knowledge would be (the admittedly hugely challenging) development of 'ecological thinking':

... perhaps the first subject-matter that transcends or shatters discourse boundaries and strains both imagination and human powers when selecting between conceptual frameworks ... ${ }^{1}$

Kaldis questions whether the 'disciplinary borrowing' that commonly features in emerging ecological thinking discourse is '... merely unfortunate? Or is it, rather, logically inescapable?', seeing it as an inevitable route to social constructionism and anthropocentrism. ${ }^{1}$ I would argue, in common with eco-pragmatists, ${ }^{1}$ that given the pan-dimensional issues involved, disciplinary borrowing is inevitable - but that it is also desirable, though requiring careful handing in order to avoid the mere absorption of ecological insights into current discourse, rather than their application prompting a transformation therein. One consequence of the need to develop ecological thinking is that emerging scientific discourse at the very frontiers of the human/environment interface is increasingly being brought to the fore in informing discussion of the hard choices that we face. The influential work of the Stockholm Resilience Centre (SRC) on planetary boundaries is prominent in this regard. ${ }^{1}$ Of particular interest in the current context is the holistic, systemic, and, biospherebased approach being adopted by the SRC - the Earth System perspective - to evaluating the impacts

\footnotetext{
${ }^{1}$ R. Delgado, 'Our Better Natures: A revisionist View of Joseph Sax's Public Trust Theory of Environmental Protection, and Some Dark Thoughts on the Possibility of Law Reform' 44.6 Vanderbilt Law Review 1209, 1212. 1 Jedediah Purdy, 'Our Place in the World: A New Relationship for Environmental ethics and Law' 62.4 Duke LJ (2013) 857.

${ }^{1}$ Discussed in Luis A. Vivanco, Green Encounters: Shaping and Contesting Environmentalism in Rural Costa Rica (Berghahn Books 2006) notably at 54 et seq.

${ }^{1}$ Carl Folke, Steve Carpenter, Brian Walker, M artin Scheffer, Thomas Elmqvist, Lance Gunderson and C.S. Holling, 'Regime Shifts, Resilience, and Biodiversity in Ecosystem Management' 35 (2004) Annu. Rev. Ecol. Evol. Syst. 557, 558.

${ }^{1}$ B. Kaldis, 'Could the Environment Acquire its Own Discourse?' History of Human Sciences (2003) Vol 16.373. $1 \mathrm{lbid}, 74$.

${ }^{1}$ See, for example, Daniel A Farber, Ecopragmatism, University of Chicago Press 1999, examining the interface between economics, science and environmental regulation.

${ }^{1}$ Heir apparent to the more rudimentary modelling approaches pioneered by the Club of Rome - Donella $\mathrm{H}$. M eadows, Dennis L. M eadows, Jorgen Randers, William W. Behrens III, The Limits to Growth (Universe Books 1972).
} 
of human activity on the environment. As befitting the science of the Anthropocene, human activity is viewed as an integral part of the Earth System, which is defined as:

... the integrated biophysical and socioeconomic processes and interactions (cycles) among the atmosphere, hydrosphere, cryosphere, biosphere, geosphere, and anthroposphere (human enterprise) in both spatial-from local to global-and temporal scales, which determine the environmental state of the planet within its current position in the universe. Thus, humans and their activities are fully part of the Earth System, interacting with other components. ${ }^{1}$

When applied to the nine planetary boundaries identified by the SRC, namely: the stratospheric ozone layer; biodiversity; chemicals dispersion; climate change; ocean acidification; freshwater consumption and the global hydrological cycle; land system change; nitrogen and phosphorus inputs into the biosphere and oceans; and atmospheric aerosol loadings - it is clear that the planetary system is under operating under an unprecedented slew of multidimensional, interactive, and anthropogenic, pressures. It is clear that, if these pressures are being made manifest at the planetary/biospheric level, they are also being experienced in the ecosystems which comprise much of it.

\section{(H) The Human/Nature Relationship and Ecosystems}

Individual ecosystems represent the most immediate manifestation of the human/nature nexus and therefore provide an excellent glimpse into the state, character, and viability of the human/nature relationship - and they are of course hugely significant in their own right in the current, seemingly unending, cycle of environmental degradation. ${ }^{1}$ Ecosystems may be defined as: 'the complex of a community of organisms and its environment functioning as an ecological unit'. ${ }^{1}$ Our modern understanding of ecosystems, as indicated above, encapsulates humanity within this 'community of organisms'. It also acknowledges that '... regime shifts in ecosystems are, to a large extent, driven by human actions'. ${ }^{1}$ M anaging the human/ ecosystem interface (more accurately expressed than the usual description of managing ecosystems) has therefore come to be a pressing issue and is focussed on a range of human activities ranging from: 'top-down' (encompassing the products of deliberate action); to 'bottom up' (encompassing inadvertent impacts of human activity); and 'altering disturbance regimes'. ${ }^{1}$

Whilst current discussion of the specific human/ecosystem interface is dominated by Ecosystem Services Approaches (ESAs) which we will consider shortly, these are is located in the broader ecology-driven approach that emerged in the conception of Ecosystem Based Management (EBM) of terrestrial environments in the 1960s. EBM may be defined as: 'comprehensive and integrative management decisions and actions in relation to ecosystem dynamics and the provision of interconnected ecosystem services, or human benefits. ${ }^{1}$ The concept of EBM with its strong management bent, ${ }^{1}$ despite its nomenclature, constitutionally tends to the prioritisation of human

\footnotetext{
${ }^{1} \mathrm{~J}$. Rockström et al., Planetary boundaries: exploring the safe operating space for humanity 14.2 Ecology and Society (2009) 32 http://www.ecologyandsociety.org/vol14/iss2/art32/J accessed 27 April 2016 and Steffen et al. n2.

${ }^{1}$ See, for example, Report of the Millennium Ecosystem Assessment (M EA), Ecosystems and Human Wellbeing - Synthesis Report (2005) online http://www. millenniumassessment.org/documents/document.356.aspx.pdf (accessed 27 April 2016).

${ }^{1}$ Online at http://www.merriam-webster.com/dictionary/ ecosystem.

${ }^{1}$ Folke et al. n21, 573.

${ }^{1}$ lbid.
} 
priorities. The conception of ESAs as an element of EBM, which further enhances certain human priorities in this context, emerged in scientific literature in the 1980s, rising to prominence by the late 1990s. The UN's M illennium Ecosystem Assessment ${ }^{1}$ (MEA) brought the concept to global prominence. It identified four categories of 'ecosystem services', namely: provisioning; regulating; cultural; and supporting. The signifying language of 'service' is crucial - as the: '... words we use to describe things are also the way we value them'; ${ }^{1}$ in this case value being explicitly based on the delivery of human well-being. The spectrum of services involved represents the complex and challenging mix of quantitative and qualitative elements that need somehow to be effectively combined in order to meet the multi-dimensional demands of EBM. The attraction of ESAs from a management perspective, as described by Constanza et al., lies in the recognition that:

Sustaining and enhancing human well-being requires a balance of all our assets - individual people, society, the built economy, and ecosystems. The reframing of the way we look at "nature" is essential to solving the problem of how to build a sustainable and desirable future for humanity. ${ }^{1}$

That said, while ESAs ostensibly function as a tool within EBM, the manner in which they are deployed in practice and the degree of prominence accorded to them vis-à-vis other components of EBM is of central importance. At a superficial level the conceptual origins of the concept of 'ecosystem services' in a science-driven model of EBM ${ }^{1}$ appear to be at least partially ecocentric invoking the concept of the ecosystem, of which humanity is a part, as the framing for protection. In real terms however currently ESAs are driven by economics rather than science. ${ }^{1}$ The explicit harnessing of ESAs to economics, in effect stressing 'services' above 'ecosystems' is a deliberate policy choice, reflecting dominant social mores. Nowhere is this bent more clearly exemplified than in the six reports on 'The Economics of Ecosystems and Biodiversity' (TEEB). ${ }^{1}$ These brought consideration of the valuation of ecosystems into the mainstream in international affairs, and formed a central plank of the wider 'green economy' initiative in the run up to the UNCSD (Rio+20) in 2012. Despite a somewhat lukewarm reception for the concept of the green economy in general at the conference, ${ }^{1}$ the ESA strand of the initiative seems to have a sustained momentum of its own. ${ }^{1}$

\footnotetext{
${ }^{1}$ Crow White, Christopher Costello, Bruce E. Kendall and Christopher J. Brown, 'The value of coordinated management of interacting ecosystem services', 15.6 Ecology Letters (2012) 509, 509.

${ }^{1}$ See Kaldis $\mathrm{n} 22,85$ on the orientation of management approaches.

1 MEA, n27.

${ }^{1}$ P. Evans, 'Reclaiming the Language' in Caught by the River: On Nature: Unexpected Ramblings on the British Countryside HarperCollins 2011, 107.

${ }^{1}$ Robert Constanza et al., 'Changes in the global value of ecosystem services' 26 Global Environmental Change
} (2014) $152,153$.

JJan M CP. Dick, Rognvald I. Smith, and E. Marian Scott, 'Ecosystem Services and Associated Concepts', 22 Environmetrics (2011), 598.

${ }^{1}$ lbid.

${ }^{1}$ For the sake of practicality, discussion here will focus specifically on the synthesis report drawn from these: The Economics of Ecosystems and Biodiversity: Mainstreaming the Economics of Nature: A Synthesis of the Approach, Conclusions and Recommendations of TEEB, (TEEB Synthesis) (2010) at www.teebweb.org (accessed $25 / 10 / 11$ ) which provides an overview of the work as a whole.

${ }^{1}$ Discussed in K. Morrow, 'Rio +20, the Green Economy and Re-orienting Sustainable Development' 14.4 Environmental Law Review (2012) 279.

${ }^{1}$ Rio +20 Outcome Document, A/RES/66/288, The Future We Want online https:// documents-ddsny.un.org/doc/UNDOC/GEN/N11/476/10/PDF/N1147610.pdf? OpenElement accessed 27 April 2016, para 91. UNGA RES 70/ 1. Transforming our world: the 2030 Agenda for Sustainable Development (The Sustainable Development Goals) online http://www.un.org/en/ga/search/view_doc.asp?symbol=A/RES/70/1 (accessed 27 April 2016), makes 
While the TEEB initiative was hosted by UNEP, it was initiated by the G8+5 as a part of the antidote to the burgeoning global economic crisis. To this end, it aspired to tackle the 'economic invisibility' of most ecosystem services and 'mainstream' the environment into financial services by incorporating the 'values of nature' into societal decision-making processes at all levels. ${ }^{1}$ This ostensibly acknowledged the centrality of ecosystem health to a viable economy. Furthermore, in positing a more economically grounded approach to environmental protection, it sought to:

... provide a bridge between the multi-disciplinary science of biodiversity and the arena of international and national policy as well as local government and business practices. ${ }^{1}$

Furthermore, the TEEB characterised the established relationship between humanity and nature as one of 'self-destructiveness' ${ }^{1}$ and viewed attributing monetary value to ecosystem services as a potent corrective to it, stating that:

Valuation can act as a powerful form of feedback, a tool for self-reflection, which helps us rethink our relation to the natural environment and alerts us to the consequences of our choices and behaviour on distant places and people. ${ }^{1}$

The TEEB further envisaged:

... the introduction of mechanisms that incorporate the values of ecosystems into decision making through incentives and price signals. ... It needs to come along with reinforcing rights over natural resources and liability for environmental damage. ${ }^{1}$ (emphasis in the original)

Thus the TEEB advocated the adoption of ESAs, which it defined as evaluating; 'flows of value to human societies as a result of the state and quantity of natural capital'. ${ }^{1}$ Taken in context, it is clear then that, despite its 'ecosystem' nomenclature, what was being advocated by ESAs here was not only (like EBM ) fundamentally anthropocentric but also primarily economic in approach. ${ }^{1}$ This has appeal, notably in seeking to address market failures, specifically: the fact that pricing of ecosystem services had tended to be confined to use values (e.g. provisioning services) with non-use values (e.g. cultural services) rarely being considered in monetary terms; and seeking to encapsulate indirect use values (regulating services) which are only beginning to be assigned economic value, though they in fact make the most significant contribution to human well-being. ${ }^{1}$ There are however significant problems attached to the TEEB's conception of ESAs, not least those related to valuation. In principle, pricing ecosystem services arguably further commodifies/objectifies the natural world, reinforcing the paradigm of mastery. Furthermore, focussing narrowly on economics reinforcing the dominance of market-based ideologies and ultimately represents a damagingly reductionist attempt

frequent reference to ecosystems, referring to ecosystem services in Goal 15.1, indicating the continuing currency of the concept, committing to: 'By 2020, ensure the conservation, restoration and sustainable use of terrestrial and inland freshwater ecosystems and their services ...'.

${ }_{1}^{1}$ TEEB Synthesis $n 383$.

${ }^{1} \mathrm{lbid}, 4$.

${ }^{1} \mathrm{lbid}, 12$

${ }^{1}$ lbid.

${ }^{1}$ lbid.

${ }^{1} \mathrm{lbid}, 7$.

${ }^{1}$ Nükhet Yilmaz Turgut, 'The influence of ecology on environmental law: challenges to the concept of traditional law', 10 Environmental Law Review (2008) 112.

${ }^{1}$ TEEB Synthesis, n38, 7-8. 
at the quantification of qualitative considerations. ${ }^{1}$ Even if these objections are overlooked as idealistic/ideological, and we accept the assertion that engaging with the market is necessary in order to protect ecosystems, the practical problem of ascribing appropriate monetary value to ecosystem services remains. In order for ESAs to improve upon current approaches, they would need to attain a degree of accuracy in valuing the services in question - otherwise they will simply serve to add spurious legitimacy to erroneous assumptions. At a minimum this would require them to be founded on a thorough, science-based, understanding of ecosystems coupled with due consideration of human systemic impacts on and interactions with them. The difficulties of capturing value in this context are exacerbated by the fact that our baseline knowledge of ecosystems generally, ${ }^{1}$ let alone ecosystem services, is poor, with our limited understanding of ecosystem function and maintenance, critical thresholds, uncertainty, and precaution, all raising serious concerns. Additionally, arguments for the valorisation of ESAs would be considerably more convincing if our well-established attribution of economic value to the considerably more straightforward category of environmental goods was such as to ensure their sustainable use. In fact, experience has shown that : '... admitting the traditional economic valuation methods almost always undervalues biological diversity ....'. ${ }^{1}$ Furthermore, expanding the role of the market in such contexts only provides protection to the environment '... unless degrading it becomes more profitable. ${ }^{1}$ In light of this, sending out inaccurate price signals on ESAs would have potentially disastrous consequences, yet proponents argue for their potential draw income from 'wildlands' through giving the invisible hand of the market a 'green thumb'. ${ }^{1}$

Such issues notwithstanding, the TEEB asserts that the process of pricing ESAs: '... should be uncontroversial for many ecosystem services, especially at the local scale ${ }^{1}$ yet at the same time it acknowledges that the process presents enormous challenges. ${ }^{1}$ Bennett engages with the latter noting that, while our knowledge base is developing:

... despite extensive work on ecosystem services in recent decades, our understanding of their ecological foundation, their impacts on human well-being, and our knowledge about how to govern their benefits remains insufficient. ${ }^{1}$

Our fragmented knowledge base was initially largely confined to conceptual consideration of interactions between hard science (incomplete it itself) and economics, which, while challenging in itself, in no wise reflected the full complexity of the issues involved. Latterly, the social sciences ${ }^{1}$ and empirical study ${ }^{1}$ are beginning to play a more prominent role in this regard, countering the established dominance of scientific and economic information sets. While on one level this is all to the good, it is also the case that, as the range of inputs increases, the challenges posed by cross disciplinary dialogue become, in anything, more vivid. ${ }^{1}$

\footnotetext{
${ }^{1}$ Mark Sagoff, 'On the value of natural ecosystems: The Catskills parable', Politics and the Life Sciences 21 (2002), 19-25.

${ }^{1}$ G.C. Daily et al., 'The Value of Nature and the Nature of Value', Science, 289, Issue 5478 (2000), 395.

${ }^{1}$ S.B. Banerjee, 'Who Sustains Whose Development? Sustainable Development and the Reinvention of Nature', 24(1) Organization Studies (2003) 143, 156.

1 lbid, 153.

${ }^{1}$ E.O. Wilson, The Diversity of Life (Harvard University Press 1992) 271.

1 TEEB Synthesis n38, 25.

1 lbid, 12.

${ }^{1}$ Elena M. Bennett et al., 'Linking biodiversity, ecosystem services, and human well-being: three challenges for designing research for sustainability' 14 Current Opinion in Environmental Sustainability (2015) 76, 77.

${ }^{1}$ David K Loomis, Shona K. Paterson, 'Human dimensions indicators of coastal ecosystem services: A hierarchical perspective' 44 Ecological Indicators 44 (2014) 63.

${ }^{1}$ See, for example, Herbert W. Schroeder, 'Place experience, gestalt, and the human-nature relationship' Journal of Environmental Psychology 27 (2007) 293.
} 
In the end, the TEEB, despite employing a slew of expertise in its deliberations, ended up merely paying lip-service to the plurality of disciplines in play, opting for a mainstream economic approach, reliant on the popular but highly problematic (demand-led, hypothetical) concept of 'willingness to pay' ${ }^{1}$ as the basis for valuation. This reductionist stance misses the point, for, as Stone observes, the: '... environmental "values" of which we are now speaking are by definition over and above those that the market is prepared to bid for: they are priceless. ${ }^{\prime}$

The approach to valuation of ESAs advocated by the TEEB is at best implausible and at worst woefully inadequate, sidestepping the real challenge that we face which is, as Adelman puts it: '... to develop a notion of sustainability within rather than against nature. ${ }^{\prime 1}$ Instead ESAs as currently construed arguably represent a retrograde step as, not only are they anthropogenic in focus, they in fact even narrow the range of human concerns addressed by foregrounding economic considerations at the expense of other relevant factors. The only viable - if undoubtedly socially and economically painful approach would be to build our economic system on respect for ecological limits as a constraining foundation for this aspects and all other aspects of human endeavour. So, can ESAs deliver this? As currently envisaged that answer has to be no: in reality what they offer is a further manifestation of 'business as usual' though this has obvious if superficial attractions, not least in the creation/augmentation of existing property rights ${ }^{1}$ and associated facilitation of payment, offset, trade and substitution in environmental credits. Thus for all their flaws, ESAs are already, despite their flaws, being embraced with some enthusiasm by international institutions, governments, the business community, and to some degree in popular culture. ${ }^{1}$

(H) Is It Possible to Re-Orient ESAs? A Preliminary Exploration Rights-based Approaches

(SH) Property Rights, ESAs, and PES

Proponents of ESAs, such as Constanza et al. are at pains to stress that their valuation is not about ownership/ privatisation, but rather:

... their value in monetary units is an estimate of their benefits to society expressed in units that communicate with a broad audience. This can help raise awareness of the importance of ecosystem services to society and serve as a powerful and essential communication tool to inform better, more balanced decisions ... ${ }^{1}$

Nonetheless, once we place an economic value on something, it inevitably becomes the subject of property rights that are owned and traded; this inevitably and significantly alters the dynamics of the relationships clustered around it. The TEEB for example, in alluding to 'reinforcing rights over natural resources ${ }^{\prime}$ clearly envisaged an extension of property rights in this context - facilitated by the fact

\footnotetext{
${ }^{1}$ See. For example, Loomis and Paterson, n57, and Bennett n56.

${ }^{1}$ TEEB Synthesis, n38, 4.

${ }^{1}$ Stone, n8, 476.

${ }^{1}$ Sam Adelman, 'Rio+20: sustainable injustice in a time of crisis' 4.1 (2013) Journal of Human Rights and the environment $6,10$.

${ }^{1}$ See, with regard to the EUETS, Armstrong DLW GmbH v Winnington Networks Ltd [2012] EWHC 10 (Ch) in which the Court considered the legal status of an emissions trading allowance (EUA). Both parties regarded the EUA as property (para 40), a view with which the Court concurred (para 50).

${ }^{1}$ See, for example, considering the broader issue of natural capital, within which ESAs are located, Mary Catherine O'Connor: 'Can you put a price on nature? A Californian nonprofit thinks it can' Guardian, Sunday 13 March 2016.

${ }^{1}$ Constanza et al n35, 157.

${ }^{1}$ TEEB, n38, 12.
} 
that many ESAs are located on land and that payments for ecosystem services (PES) will be tied to the existing legal rights that manifest in this regard. Thus ESAs, rather than adopting ecological thinking and developing conceptions of the environment as 'provider of basic (human) needs', ${ }^{1}$ can be viewed as further extending the conception of the environment as property, with damaging environmental and social consequences. ${ }^{1}$

Individual property rights arising in the context of PES would naturally raise concerns akin to those raised by of property rights in land and the environment more generally in that, while an individual property owner/occupier may be disposed to protect the environment, ${ }^{1}$ there is no obligation on them to do so. ${ }^{1}$ There are however already models in place that partially engage with the need to attenuate individual property rights in the name of the broader public interest in the environment. Some are primarily negative in their approach, employing various forms of coercive control - for example, requiring the grant of state permission in order to lawfully develop land; or rendering certain activities unlawful (such as the use of fertilizer in areas vulnerable to nitrate pollution) in the name of environmental protection. Such regimes are often contentious and generate considerable potential for legal challenge. PES on the other hand offers a species of positive incentivisation, which like certain nature conservation initiatives, pays landowners/ occupiers to act, or refrain from acting, for the benefit of the environment, albeit in the narrower context of species or habitat protection. However, this type of approach too has proven contentious, not least in generating property rights based litigation. ${ }^{1}$ In any case it is arguable that, where PES are concerned, individual property rights would need to undergo considerable adaptation/only play a role within broader arrangements countenancing the public interest in order to be applied effectively to the governance of ESAs. ${ }^{1}$

Additionally, where PES are concerned, reasoning by extension from the approach adopted to the similarly artificial market-based construct of tradeable emissions permits, ${ }^{1}$ they could be construed as intangible property. In the alternative, PES could be treated as akin to an environmental license/permit - which may be more apposite as they are conditional upon mandated behaviours being observed; they would also constitute property on this view. ${ }^{1}$ There are important commonalities between tradeable emissions permits and environmental licences in that they offer individual benefit to their owners, chiefly in allowing them to operate lawfully, albeit against a backdrop of realising regulatory priorities in the public interest (and in the former case profiting from efficiency in so doing); PES are not quite analogous, in that they incentivise certain actions/refraining therefrom by landowners/ occupiers in the public interest but this alone would not preclude like treatment being accorded to them.

\section{(SH) Other Human Rights, Rights for Nature, and ESAs}

In terms of accommodating the broader public interest in ESAs, both the compulsive and incentivist approaches referred to above are strongly statist in their orientation and essentially bipartite in

\footnotetext{
${ }^{1}$ Derek R. Bell, 'Liberal Environmental Citizenship' (2005) Environmental Politics Vol. 14 No. 2 179, 180.

${ }^{1}$ See, for example, George Monbiot, 'Putting a price on the rivers and rain diminishes us all' Guardian 6 August 2012.

${ }^{1}$ As for example NGOs running preserves - discussed in Vivanco, n20.

${ }^{1}$ Discussed at length in Stone, $\mathrm{n} 8$.

${ }^{1}$ See K. Morrow, 'European Habitat Conservation Activities and Individual Property Rights: Law and the Meaning of LIFE', 17 Italian American Law Digest, Vol. 17, (2009) 301.

${ }^{1}$ See Richard A. Barnes, The Capacity of Property Rights to Accommodate Social-Ecological Resilience' 18.1 Ecology and Society (2013) 6.

${ }^{1}$ See Armstrong DLW GmbH v Winnington Networks Ltd n63.

${ }^{1}$ See In re Celtic Extraction Ltd [2001] Ch 475 in which the court found that a waste management licence fell within the definition of 'property' under 5436 of the Insolvency Act 1986.
} 
nature, focussing on the relationship between the state as regulator/incentive provider and landowners/ occupiers; the statist focus is ameliorated only to the extent that they effectively incorporate public participation. Delivering meaningful public participation would be particularly demanding in respect of ESAs and PES, given that many ecosystem services provide for complex, indivisible, social and/or collective goods, rather than the 'things' (provisioning services partially excepted) that form the traditional province of private property. This renders the extension of property rights in their traditional form into this emerging arena inherently problematic, largely because the collective benefits in question extend well beyond individual landowners, to neighbouring communities, regions, and even (in some cases) the globe, and are highly unsuitable subjects for individuation.

Furthermore, when private property rights have been extended into new realms in the past, as for example with the introduction of individual ownership regimes to land previously held in common under indigenous regimes, in enclosure, ${ }^{1}$ and under colonialism. ${ }^{1}$ These developments saw the introduction of individual property into spheres that had previously accommodated collective resource holding regimes and the associated further concentration of economic benefit in the hands of a privileged, wealthy, minority at the expense of excluded, poor, minorities. ${ }^{1}$ These developments commodified ${ }^{1}$ and corporatized ${ }^{1}$ land as a resource, generating conflict and adverse social and environmental impacts. In the context of the former Richards points out that:

Perhaps the most typical conflict ... is that over the exploitation of a natural resource that has become valuable and marketable. ... Issues of stability, tradition, and nostalgia are pitted against the excitement of new wealth and productivity in internecine elite conflict. ${ }^{1}$

In respect of the environmental problems that have arisen in this context, Rangarajan observes that: 'The twin themes of the decline of older patterns of landuse and the degradation of ecosystems are interwoven ....'. It seems reasonable to infer that, as PES commodify collective ecosystem services, which are themselves attached to land, they have the potential to generate similar social and environmental conflicts.

Likewise, there are also potential parallels to be drawn between the introduction of PES and the creation of both government ${ }^{1}$ and NGO-owned habitat and species preserves for study/ ecotourism, ${ }^{1}$ in employing (now largely discredited ${ }^{1}$ ) 'fortress conservation', effectively commodifying aspects of ecosystems: appropriating control of them; deriving income from them; and excluding local/indigenous communities from benefits and resources to which they traditionally had access. In all of these cases, the traditional human element of the ecosystems in question is effectively stripped out and replaced with a modern one, which can pay for the privilege.

\footnotetext{
1 Monbiot n68.

${ }^{1}$ John F. Richards, 'Toward a Global System of Property Rights in Land', in Edmund Burke III and Kenneth Pomeranz (eds.), The Environment in World History (University of California 2009).

${ }^{1}$ See for example, International Institute for Environment and Development, 'Markets and payments for environmental services' online http://www.iied.org/markets-payments-for-environmental-services (accessed 05 M ay 2016)

${ }^{1}$ Richards, n76, 58.

$1 \mathrm{lbid}, 71$.

1 lbid, 73.

${ }^{1}$ M ahesh Rangarajan, 'Environmental Histories of India: Of States, Landscapes, and Ecologies' in Burke and Pomeranz (eds.) n76, 238.

${ }^{1}$ See Jane Roberts, Environmental Policy (2 ${ }^{\text {nd }}$ edn.) (Routledge 2011) 79-80.

${ }^{1}$ See Vivanco, n20.

1 lbid, 55-6.
} 
In recent times precisely such closures have been important in promoting the use of human rights claims based on broadly environmental claims - a development that has, at least in part, has been the product of the failure of environmental law to adequately address the pressure points posed by the impacts of environmental degradation on people. ${ }^{1}$ This has been an essentially pragmatic course of action, but it has proved complex and piecemeal and it is not an unalloyed success. Nonetheless, it is now an established part of the international legal landscape ${ }^{1}$ and it may have some application to the tempering the adverse impacts of ESAs on the interests of human communities and by extension (at least in some cases) on the natural world. At the very least, in potentially extending the range of relevant considerations beyond the purely economic, importing certain classes of human rights-based argument can at least serve to open up the issues up to fuller consideration.

A potential corrective to an individual property rights focus in ESAs, and one that more accurately reflects the broader role and value of ecosystem services, could be achieved by employing rights claims in order to give legal cognisance to the fact that many of them - in particular those falling into the regulating, supporting, and cultural categories are, wholly or in part, collective and indivisible in nature. Thus safeguarding the interests of the people who benefit from these ecosystem services, but do not own the host land, would require a novel form of engagement with human rights, eschewing the solely individualistic focus that dominates current human rights law in favour of a more collective slant. This type of approach found expression in the soft law United Nations Declaration on the Rights of Indigenous Peoples ${ }^{1}$ (UNDRIP) which (although it does not specifically refer to ecosystems) not only recognises the conception of collective rights in the respect of the environment, ${ }^{1}$ but also that these are founded upon a very different conception of the relationship between humanity and the environment than that which prevails in current thought. The former is evident in the Declaration's acknowledgement of the right of indigenous peoples, as collective entities, to the: '... conservation and protection of the environment and the productive capacity of their lands or territories and resources' and consequent invocation of state obligations in this regard. ${ }^{1}$ The latter finds partial expression in the preambular provision which recognises that: '... that respect for indigenous knowledge, cultures and traditional practices contributes to sustainable and equitable development and proper management of the environment' and in the body text in relation to protection for indigenous:

... cultural heritage, traditional knowledge and traditional cultural expressions, as well as the manifestations of their sciences, technologies and cultures, including human and genetic resources, seeds, medicines, knowledge of the properties of fauna and flora [etc.] ...'

and intellectual property therein; ${ }^{1}$ coupled with rights to determine resource development/ use within their lands or territories; and associated rights of redress for interference (including express reference to environmental impacts) with them. ${ }^{1}$ These provisions are sufficiently broadly drafted to

\footnotetext{
${ }^{1}$ Penelope Simons: 'Selectivity in law-making: regulating extraterritorial environmental harm and human rights violations by transnational extractive corporations' in Anna Grear and Louis Kotze (eds) Research Handbook on Human Rights and the Environment Edward Elgar, Cheltenham, (2015) points out that while international environmental law instruments tend to be particularly lacking in terms of compliance mechanisms in comparison to international human rights law regimes, at 486.

${ }^{1}$ Ken Conca, 'Environmental Governance After Johannesburg: From Stalled Legalization to Environmental Human Rights' (2005) 1 Journal of International Law and International Relations 122, 133.

${ }^{1}$ United Nations General Assembly (2007) Resolution 61/295 'Declaration on the Rights of Indigenous Peoples (UNDRIP) at http://www.un.org/esa/socdev/unpfii/documents/DRIPS en.pdf (accessed 06 M ay 2016).

${ }^{1} \mathrm{M}$. Barelli, 'The role of soft law in the international legal system: the case of the United Nations Declaration on the Rights of Indigenous Peoples' 58.4 International and Comparative Law Quarterly (2009) 957.

1 UNDRIP n87, Article 29.

${ }^{1} \mathrm{lbid}$, Article 31.

${ }^{1} \mathrm{lbid}$, Article 32.
} 
accommodate all classes of ecosystem services and, read together, they arguably combine to situate our understanding of those services in a more realistic social and environmental fashion than an individualistic, property-rights style model can ever do. Nonetheless, on one level it is possible to argue that the UNDRIP approach is still essentially anthropocentric in its rights-based approach to humans and nature; this interpretation is not however borne out when considered against the background of indigenous cosmologies, as expressed for instance in the 2010 Universal Declaration of the Rights of M other Earth (UDRME) ${ }^{1}$, the preamble of which states that: '... we are all part of M other Earth, an indivisible, living community of interrelated and interdependent beings with a common destiny'. This view, founded on a common feature of many indigenous cosmologies, crucially belies the paradigm of mastery, breaking down artificial distinctions between humanity and nature. This type of approach has also played a key role in pioneering theoretical work, both philosophical ${ }^{1}$ and jurisprudential, challenging the way in which we regard the relationship between humanity and the environment. In the latter category, Stone famously made the case for changing the way law treats the natural world by extending rights claims to it, arguing that:

... the notion of something having a "right" ... brings into the legal system a flexibility and open-endedness that no series of specifically stated legal rules ... can capture. Part of the reason is that "right[s]" ... have meaning - vague but forceful - in the ordinary language and the force of these meanings, inevitably infused with our thought, becomes part of the context against which the "legal language" of our contemporary "legal rules" is interpreted." ${ }^{1}$

The extension of legal rights to nature could provide a further counterbalance to naked human economic interest in the conception of ecosystem services. This type of approach was argued for in the Great Transition Report, which sought to promote a 'rights revolution' in defence of the biosphere by invoking the 'inviolable rights of people and nature' through developing a 'natural communities and ecosystems' based approach toward rights for nature. ${ }^{1}$ The idea of rights for nature continues to be very much a live issue for debate and activism in the international arena, expressed for example in the Rights of M other Earth Treaty (part of the Peoples Sustainability Treaties (PSTs) initiative begun in the run up to the UNCSD in 2012 ${ }^{1}$ ) which begins by recognising the: 'inherent rights of 'Mother Earth and all ecosystems and species of which she is composed'; 1 and in the ongoing work of the International Rights of Nature Tribunal ${ }^{1}$ (itself rooted in the UDRME).

\section{(H) The Limits to Rights: The Question of Responsibility}

Even were we to develop a more nuanced, less individualistically focussed conception of rights in respect of ecosystem services and to extend rights coverage to nature itself, it is arguable that this would still be insufficient to fully address the issues raised by ESAs. The less prominent, but emergent question of human responsibility may offer an interesting complementary avenue which

\footnotetext{
${ }^{1}$ The Universal Declaration of the Rights of M other Earth (UDRME) online http://therightsofnature.org/universal-declaration/ (accessed 09 May 2016).

${ }^{1}$ See for example, the pioneering Aldo Leopold, A Sand County Almanac (OUP 1968) and more recently Cormac Cullinan, Wild Law: A M anifesto for Earth Jurisprudence ( $2^{\text {nd }}$ edn.) (Green Books 2011).

${ }^{1}$ Stone n8, 488.

1 P. Raskin, T Banuri, G Gallopin, P Gutman, A Hammond, R Kates and R Swart, 'Great Transition: The Promise and Lure of the Times Ahead' Global Scenario Group (Stockholm Environment Institute 2002) 59

${ }^{1}$ K. Morrow, 'Peoples Sustainability Treaties at Rio+20: Giving Voice to the Other' in P. Burdon and M. Maloney (eds.) Wild Law - In Practice (Taylor and Francis 2014).

1 Peoples Sustainability Treaties (2012) online https://sustainabilitytreaties.org/ (accessed 06 M ay 2016).

${ }^{1}$ http://therightsofnature org/rights-of-nature-tribunal-paris/ (accessed 09 M ay 2016).
} 
could be pursued to this end. Whilst the notion of legally embodying individual human responsibilities tends to have fairly limited reach in the current, state-oriented human rights cannon, 1 it occasionally becomes a live issue even in mainstream human rights debate. ${ }^{1}$ Employing the notion of responsibility in an environmental context tends to be viewed rather more enthusiastically, rooting the notion in both moral and practical terms:

... we, the most powerful species on earth, have the capability to destroy, create, modify and otherwise affect the ecosystems of the planet, their life forms and our own future' ${ }^{1}{ }^{1}$

Invoking individual and collective human responsibility towards the environment would place a limit on the pursuit of rights, responding to the unique position of humans as ecosystem actors in respect of other humans and other life forms. Such an approach is not without precedent, for example, the moral and ethical need to exercise ecological responsibility qua future generations of humans (though not in terms of nature in its own right) featured in the 1997 UNESCO Declaration on the Responsibilities of the Present Generations Towards Future Generations. ${ }^{1}$ Article 4 of this document, on the 'Preservation of life on Earth', states that:

... Each generation inheriting the Earth temporarily should take care to use natural resources reasonably and ensure that life is not prejudiced by harmful modifications of the ecosystems and that scientific and technological progress in all fields does not harm life on Earth.

The idea of human responsibility tends to be more prominently endorsed by environmental activists than their human rights counterparts and it has re-emerged in Article 3 of the UDRM E, which delineates broad-ranging and detailed obligations applicable to all human beings to: 'respect, protect, conserve and where necessary, restore the integrity, of the vital ecological cycles, processes and balances of M other Earth'. ${ }^{1}$ PSTs too considered this issue, notably in the Charter of Universal Responsibilities (CUR) ${ }^{1}$ which advocated an expansion of human rights-based approaches that recognised the 'interdependences' between 'humankind and the biosphere' ${ }^{1}$ and an '.... awareness of our shared responsibilities to the planet' as a 'condition for the survival and progress of humankind'. ${ }^{1}$ These days we can ill-afford to scoff at such thinking as mere idealism - instead, in light of the enmeshed environmental crises we face and the potential existential threats that they pose, it should be viewed an expression of realism.

Were ESAs to be engaged with through a sustainability lens, then their environmental importance would be the prime consideration, the base line against which their social and economic importance

\footnotetext{
${ }^{1}$ See, for example, The International Council on Human Rights Policy, Taking Duties Seriously: Individual Duties in International Human Rights Law - A Commentary' (1999) online http://www.ichrp.org/files/reports/10/103 report en.pdf (accessed 20 April 2016).

${ }^{1}$ Notably in a civil society context, see the 1997 Inter Action Council, A Universal Declaration of Human Responsibilities http:// interactioncouncil.org/universal-declaration-human-responsibilities (accessed 20 April 2016).

${ }^{1}$ Stephen T. Trudgill, Barriers to a better environment: What stops us solving environmental problems? (Belhaven Press 1990) 13.

${ }^{1}$ Online at http://portal. unesco.org/en/ev.php-URL ID=13178\&URL DO=DO TOPIC\&URL SECTION=201.html accessed 29 April 2016.

${ }^{1}$ Article 2(f) UNDME n92.

1 Online

https:// docs.google.com/viewer?url=http $\% 3 \mathrm{~A} \% 2 \mathrm{~F} \% 2 \mathrm{Fsustainabilitytreaties.files.wordpress.com \% 2F2012 \% 2F0}$ 5\%2Fpeoples-sustainability-treaty-on-a-charter-of-universal-responsibility-draft-for-rio20.pdf (accessed 20 April 2016).

1 Ibid, principle 1

$1 \mathrm{lbid}$, principle 5.
} 
would be assessed and invoking broader rights talk in this regard could help to achieve the reorientation necessary to render them ecologically literate and effective.

\section{(H) Concluding Thoughts}

All things have their time, and the shift from the newly recognised Anthropocene to what may be termed the biocene may well be inevitable; such a transition, instituted by damaging the ecosystem services that promote human flourishing and breaching Earth System tipping points, is likely to occur in less than the blink of an eye in comparison to that between other epochs. The role of humanity in the era to come remains to be seen, for while life will continue to flourish, albeit perhaps in very different ways, humanity may not. As Emily Dickinson puts it:

How much can come

And much can go,

And yet abide the World! ${ }^{1}$

At least for now, our destiny is (at least partly) in our own hands. The continued flourishing of humanity will however require nothing less than a new ecological enlightenment. This cannot take the form of an anti-anthropocentric model - in light of humanity's distinctive position within the biosphere this would be at best implausible (if not impossible ${ }^{1}$ ) - but must rather entail the adoption of a new world view. This must be ecologically contextualised and fully understand what it means to be human; embedded in the environment but also in a unique position to shape and influence it and sees us act accordingly.

\footnotetext{
${ }^{1}$ From Emily Dickinson, 'There came a Wind like a Bugle' in Alice Oswald (ed.) The Thunder M utters: 101 Poems for the Planet (Faber and Faber 2005), 24.

${ }^{1}$ Kaldis n22, 87.
} 
Bibliography

Adelman S, 'Rio+20: sustainable injustice in a time of crises' 4.1 (2013), JHRE 6

Barelli $M$, 'The role of soft law in the international legal system: the case of the United Nations Declaration on the Rights of Indigenous Peoples' 58.4 International and Comparative Law Quarterly (2009) 957

Barnes R A, The Capacity of Property Rights to Accommodate Social-Ecological Resilience' 18.1 Ecology and Society (2013) 6

Banerjee S B, 'Who Sustains Whose Development? Sustainable Development and the Reinvention of Nature', 24(1) Organization Studies (2003) 143

Bell D R, 'Liberal Environmental Citizenship' 14.2 Environmental Politics (2005) 179

Bennett $E$ M et al., 'Linking biodiversity, ecosystem services, and human well-being: three challenges for designing research for sustainability' 14 Current Opinion in Environmental Sustainability 201576

Conca K, 'Environmental Governance After Johannesburg: From Stalled Legalization to Environmental Human Rights' (2005) 1 Journal of International Law and International Relations 122

Constanza R et al., 'Changes in the global value of ecosystem services' 26 Global Environmental Change (2014) 152

Cullinan C, Wild Law, A M anifesto for Earth Jurisprudence ( $2^{\text {nd }}$ edn.) (Green Books 2011)

Daily G C et al., 'The Value of Nature and the Nature of Value', Science, 289, Issue 5478 (2000), 395

Delgado R, 'Our Better Natures: A revisionist View of Joseph Sax's Public Trust Theory of Environmental Protection, and Some Dark Thoughts on the Possibility of Law Reform' 44.6 Vanderbilt Law Review 1209

Farber D A, Ecopragmatism (University of Chicago Press 1999)

Folke C, Carpenter S, Walker B, Scheffer M, Elmqvist T, Gunderson L and Holling CS, 'Regime Shifts, Resilience, and Biodiversity in Ecosystem Management' 35 Annu. Rev. Ecol. Evol. Syst. (2004) 557

Grim J A, Indigenous traditions and ecology: the interbeing of cosmology and community (Harvard University Press 2001)

Hantula D A, 'Evolutionary Psychology and Consumption 20.9 Psychology \& Marketing (2003) 757

Heckhausen J, 'Evolutionary perspectives on human motivation' 43.6 The American Behavioral Scientist (2000) 1015

International Council on Human Rights Policy, 'Taking Duties Seriously: Individual Duties in International Human Rights Law - A Commentary' (1999) online http://www.ichrp.org/files/reports/10/103_report_en.pdf (accessed 20 April 2016) 
International Institute for Environment and Development, 'Markets and payments for environmental services' online http://www.iied.org/markets-payments-for-environmental-services (accessed 05 May 2016)

Kaldis B, 'Could the Environment Acquire its Own Discourse?' 16.3 History of Human Sciences (2003) 73

Leopold A, A Sand County Almanac (Oxford University Press 1968)

Loomis D K, Paterson S K, 'Human dimensions indicators of coastal ecosystem services: A hierarchical perspective' 44 Ecological Indicators 44 (2014) 63

Macdonald C, and Norman W, 'Rescuing the Baby from the Triple-Bottom-Line Bathwater: A Reply to Pava' 17:1 2007 Business Ethics Quarterly 111

Marshall G, Don't Even Think About It: Why Our Brains Are Wired to Ignore Climate Change (Bloomsbury 2014)

Millennium Ecosystem Assessment: Ecosystems and Human Wellbeing - Synthesis Report (2005) online http://www. millenniumassessment.org/documents/document.356.aspx.pdf

Meadows D H, M eadows D L, Randers J, Behrens III W W, The Limits to Growth (Universe Books 1972)

Morrow K, 'Peoples Sustainability Treaties at Rio+20: Giving Voice to the Other' in P. Burdon and M. Maloney (eds.) Wild Law - In Practice (Taylor and Francis 2014)

Morrow K, 'Rio +20, the Green Economy and Re-orienting Sustainable Development' 14.4 Environmental Law Review (2012) 279

Morrow K, 'European Habitat Conservation Activities and Individual Property Rights: Law and the Meaning of LIFE', 17 Italian American Law Digest (2009) p301

Oswald A (ed.), The Thunder M utters: 101 Poems for the Planet (Faber and Faber 2005)

Peoples Sustainability Treaties (2012) online https://sustainabilitytreaties.org/ (accessed 6 M ay 2016)

Plumwood V, Feminism and the Mastery of Nature (Routledge 1993)

Plumwood V, 'Ecological Ethics from rights to recognition: multiple spheres of justice for humans, animals and nature.' In Nicholas Low (ed.) Global Ethics and Environment (Routledge 1999)

Purdy J, 'Our Place in the World: A New Relationship for Environmental Ethics and Law' 62.4 Duke L (2013) 857

Rangarajan M, 'Environmental Histories of India: Of States, Landscapes, and Ecologies' in Edmund Burke III and Kenneth Pomeranz (eds.), The Environment in World History (University of California, 2009) 
Raskin P, Banuri T, Gallopin G, Gutman P, Hammond A, Kates R, and Swart, 'Great Transition: The Promise and Lure of the Times Ahead' Global Scenario Group (Stockholm Environment Institute 2002) 59

Richards, J F, 'Toward a Global System of Property Rights in Land' in Edmund Burke III and Kenneth Pomeranz (eds.), The Environment in World History (University of California, 2009)

Rockström J, et al. , Planetary boundaries: exploring the safe operating space for humanity. 14.2 Ecology and Society (2009) 32

Schroeder H W, 'Place experience, gestalt, and the human-nature relationship' Journal of Environmental Psychology 27 (2007) 293

Simons $P$, 'Selectivity in law-making: regulating extraterritorial environmental harm and human rights violations by transnational extractive corporations' in Anna Grear and Louis Kotze (eds.) Research Handbook on Human Rights and the Environment (Edward Elgar 2015)

Steffen W et al, 'Planetary Boundaries: Guiding human development on a changing planet' (2015) Science Vol. 347 no. 622315 January 2015, DOI: 10.1126/science.1259855

Stone C D, 'Should Trees Have Standing - Towards Legal Rights for Natural Objects' 45 (1972) Southern California Law Review 450

Trudgill ST, Barriers to a better environment: What stops us solving environmental problems? (Belhaven Press 1990)

Turgut $\mathrm{N} Y$, 'The influence of ecology on environmental law: challenges to the concept of traditional law', 10 Environmental Law Review (2008) 112

United Nations General Assembly (2012) Resolution 66/288 'The Future We Want' online https:// documents-dds-ny.un.org/doc/UNDOC/GEN/N11/476/10/PDF/N1147610.pdf?OpenElement (accessed 6 M ay 2016)

United Nations General Assembly (2007) Resolution 61/295 'Declaration on the Rights of Indigenous Peoples at http://www.un.org/esa/socdev/unpfii/documents/DRIPS_en.pdf (accessed 06 May 2016)

Vivanco L A, Green Encounters: Shaping and Contesting Environmentalism in Rural Costa Rica (Berghahn Books 2006)

Weisman A, The World Without Us (Virgin Books 2008)

White C, Costello C, Kendall B E and Brown C J, 'The value of coordinated management of interacting ecosystem services', 15.6 Ecology Letters (2012) 509 